\title{
Distribution and conservation of Sciurus anomalus in Syria (Rodentia: Sciuridae)
}

\author{
Ahmad AIDEK ${ }^{1}$, Zuhair S. AMR ${ }^{2,4}$ \& Mohammad ABU BAKER ${ }^{3}$ \\ ${ }^{1}$ Directorate of Biodiversity, Ministry of Local Administration and Environment, Damascus, Syria \\ ${ }^{2}$ Department of Biology, Jordan University of Science \& Technology, Irbid, Jordan \\ ${ }^{3}$ Department of Biology, The University of Jordan, Amman, Jordan \\ ${ }^{4}$ corresponding author: amrz@just.edu.jo
}

received on 10 September 2021

\begin{abstract}
The current distribution of the Persian squirrel (Sciurus anomalus) in Syria is described based on recent observations. The species distribution extends along the coastal mountains from the vicinity of Kasab in the extreme northwest of the country, along the mountains of Lattakia and Tartus, reaching the vicinity of Damascus in the southwest, with the highest situated records from the Tartus area. Threats including hunting, trading, habitat degradation, and conflicts with local people are outlined.
\end{abstract}

Key words. Sciurus anomalus, Syria, distribution, biology, threats.

\section{INTRODUCTION}

The Persian squirrel, Sciurus anomalus Gueldenstaedt, 1785, is the only representative of family Sciuridae in the Middle East (Koprowski et al. 2016). The ecology of this species was studied in detail in Jordan and Lebanon (AmR et al. 2006, ABI-SAID et al. 2014). In Syria, the species was mentioned from Mount Hermon and from wooded areas near Damascus (TRISTRAM 1866, HARRISON \& BATES 1991, GAVISH 1993, SheHAB et al. 2018). Other records come from northern Syria including Kastel Maaf, Slenfeh, and Furlunlok Forest (von LeHManN 1965).

Within its range of distribution, three subspecies of the Persian squirrel have been recognized; Sciurus anomalus anomalus Gueldenstaedt, 1785 distributed in the Caucasus and Turkey, S. $a$. pallescens Gray, 1867 in Iraq and Iran, and S. a. syriacus Ehrenberg, 1829 in Syria, Lebanon, Jordan, and Palestine (Koprowski et al. 2016). This division is based on the differences in pelage colouration; Sciurus anomalus syriacus is described to have a dark dorsal pelage and generally dark tail and feet, $S$. a. anomalus a deep red tail, and $S$. $a$. pallescens to possess a pale back and feet, and a yellowish brown tail (HARRISON \& BATES 1991, AMr et al. 2006). However, the validity of these subspecies has been discussed (KRYŠTUFEK \& VOHRALÍK 2005, GRIMMBERGER \& RUDLOFF 2009)

In this communication, we document the distribution of the Persian squirrel in Syria and identify the current threats affecting its populations. 


\section{RESULTS AND DISCUSSION}

\section{Distribution}

We have collected sightings from 83 localities (Table 1) based on our fieldwork and published observations available in the social media. The range of Sciurus anomalus extends along the Syrian mountains, continues to cedar, oak or pine forests in Lebanon (ABI-SAID et al. 2014), reaching as far south as the Dibbeen Nature Reserve in northern Jordan (AMR et al. 2006). The species has not been recently recorded from Palestine (MENDELSSOHN \& YOM-Tov 1999).

In Syria, the distribution of Sciurus anomalus extends along the coastal mountains from the vicinity of Kasab in the extreme northwest, along the mountains of Lattakia and Tartus, reaching the vicinity of Damascus in the southwest (Fig. 1). The highest records are available from the

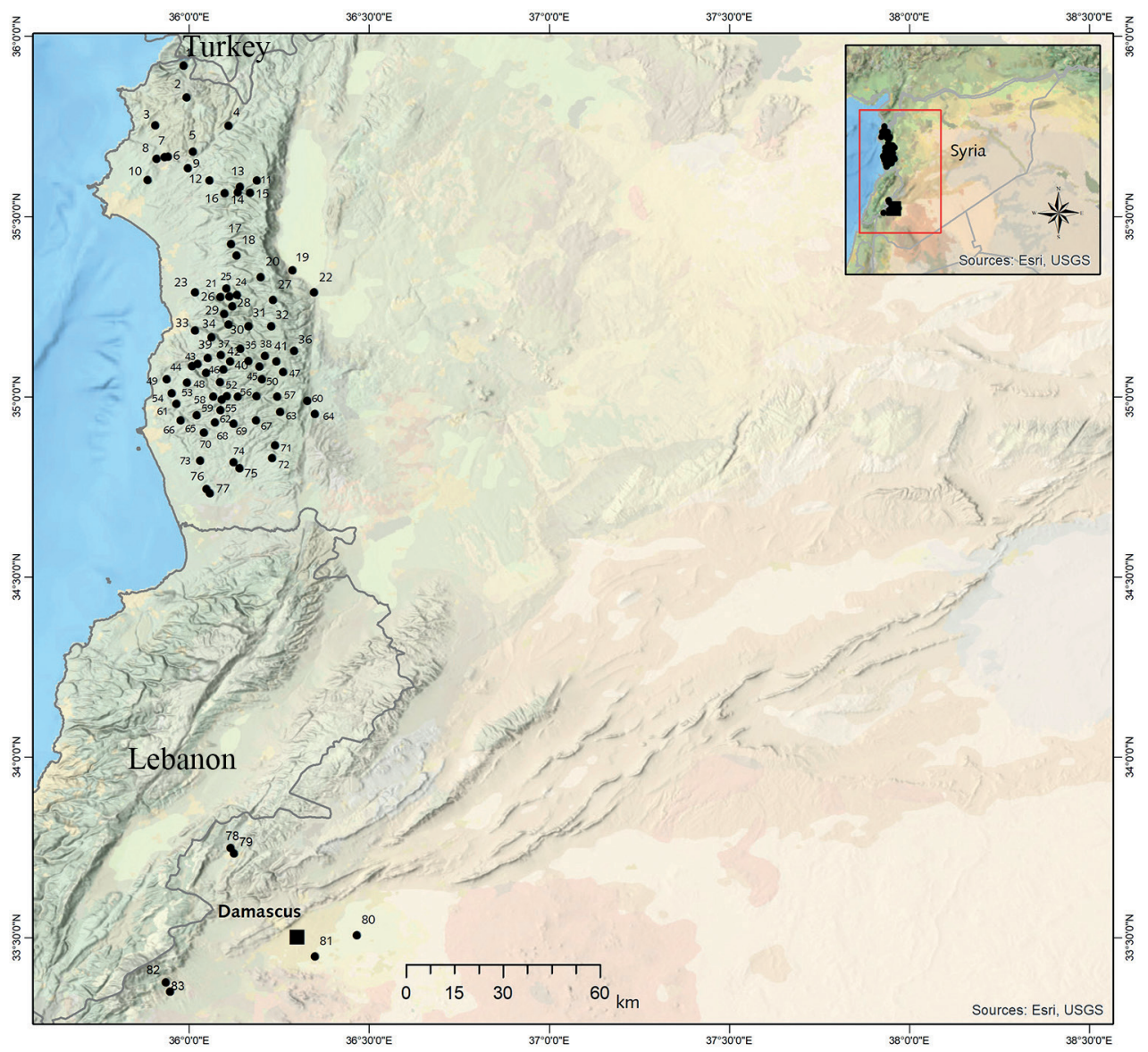

Fig. 1. Distribution of the Persian squirrel (Sciurus anomalus) in Syria (locality numbers correspond with Table 1). 
Table 1. Localities from which the Persian squirrel (Sciurus anomalus) was reported and observed in Syria

\begin{tabular}{|c|c|c|c|c|c|c|c|}
\hline No. & locality & ${ }^{\circ} \mathrm{N}$ & ${ }^{\circ} \mathrm{E}$ & No. & locality & ${ }^{\circ} \mathrm{N}$ & ${ }^{\circ} \mathrm{E}$ \\
\hline 1 & Kasab, vicinity & 35.9187 & 35.9843 & 43 & Beit Khoundah & 35.0909 & 36.0237 \\
\hline 2 & Al Furunlok & 35.8306 & 35.9935 & 44 & Sreijes & 35.0846 & 36.0085 \\
\hline 3 & Balluran & 35.7535 & 35.9057 & 45 & Al Mqarmdeh & 35.0835 & 36.1952 \\
\hline 4 & Obeen & 35.7522 & 36.1091 & 46 & Hamam Wasil & 35.0761 & 36.0949 \\
\hline 5 & Ghmam & 35.6799 & 36.0109 & 47 & Al Sheeha & 35.0684 & 36.2608 \\
\hline 6 & Mashqita Lake & 35.6662 & 35.9413 & 48 & $\mathrm{Al}$ Kreem & 35.0665 & 36.0471 \\
\hline 7 & Qarajaleh & 35.6648 & 35.9322 & 49 & Kaff Al Hamam & 35.0492 & 35.9382 \\
\hline 8 & Mashqita & 35.6603 & 35.9089 & 50 & Hammam Qenieh & 35.0488 & 36.2020 \\
\hline 9 & Az Zoubar & 35.6347 & 35.9970 & 51 & Qal'at Al Kahf & 35.0410 & 36.0854 \\
\hline 10 & Ein Al Laban & 35.6012 & 35.8846 & 52 & Al Qumsiyah & 35.0391 & 35.9937 \\
\hline 11 & Slenfeh & 35.6003 & 36.1879 & 53 & Al Hanafeiah & 35.0093 & 35.9515 \\
\hline 12 & Al Shardoub Forest & 35.5999 & 36.0567 & 54 & Breiseen & 35.0022 & 36.1046 \\
\hline 13 & Darious & 35.5824 & 36.1409 & 55 & Wadi Al Uyun & 35.0017 & 36.1865 \\
\hline 14 & Basta & 35.5680 & 36.1354 & 56 & Nabi Jaber & 35.0003 & 36.2449 \\
\hline 15 & Beshmana & 35.5659 & 36.1697 & 57 & Binjarah & 35.0000 & 36.1355 \\
\hline 16 & Ein Al Teineh & 35.5646 & 36.0989 & 58 & Abo Minqar & 35.0000 & 36.0667 \\
\hline 17 & Bakrama & 35.4241 & 36.1159 & 59 & Ash Shaykh Badr & 34.9927 & 36.0909 \\
\hline 18 & Harf Al Mseifrah & 35.3925 & 36.1323 & 60 & Al Mesherfeh & 34.9883 & 36.3277 \\
\hline 19 & Ein Elkorum & 35.3514 & 36.2866 & 61 & Ra's Kettan & 34.9808 & 35.9648 \\
\hline 20 & Al Mneizleh & 35.3326 & 36.1992 & 62 & Beit Al Maysarah & 34.9632 & 36.0873 \\
\hline 21 & Beshraghi & 35.3002 & 36.1038 & 63 & Nabi Matta & 34.9580 & 36.2534 \\
\hline 22 & Nahr Al Bared & 35.2897 & 36.3469 & 64 & B'amra & 34.9518 & 36.3500 \\
\hline 23 & Al Qteilbiyah & 35.2893 & 36.0167 & 65 & Kherbat Al Faras & 34.9484 & 36.0207 \\
\hline 24 & Pshileh & 35.2833 & 36.1333 & 66 & Bmlakah & 34.9342 & 35.9766 \\
\hline 25 & Psendiana & 35.2776 & 36.1117 & 67 & Sreighes & 34.9340 & 36.1864 \\
\hline 26 & Jaiboul & 35.2768 & 36.0869 & 68 & Baq’uo & 34.9291 & 36.0723 \\
\hline 27 & Abu Qubays & 35.2690 & 36.2330 & 69 & Jneinat Raslan & 34.9257 & 36.1233 \\
\hline 28 & Beet A'na & 35.2509 & 36.1194 & 70 & Himein & 34.9008 & 36.0412 \\
\hline 29 & Wadi Al Qal'e & 35.2296 & 36.0979 & 71 & Kafroun & 34.8656 & 36.2391 \\
\hline 30 & Ad Derdarah & 35.2005 & 36.1096 & 72 & Al Barqiyah & 34.8298 & 36.2300 \\
\hline 31 & Qal'at Al'ulayqah & 35.1962 & 36.1650 & 73 & Al Keshfeh & 34.8234 & 36.0305 \\
\hline 32 & Blouseen & 35.1957 & 36.2284 & 74 & Safita & 34.8189 & 36.1230 \\
\hline 33 & Al Dreikyiah & 35.1838 & 36.0168 & 75 & Al Mandarah & 34.8021 & 36.1397 \\
\hline 34 & Esqebleh & 35.1654 & 36.0625 & 76 & Al Areemah & 34.7438 & 36.0477 \\
\hline 35 & Al Duwaylia & 35.1330 & 36.1429 & 77 & As Sifsafeh & 34.7322 & 36.0578 \\
\hline 36 & Al Heiluna & 35.1272 & 36.2921 & 78 & Zabadani & 33.7477 & 36.1148 \\
\hline 37 & Al Smeihiyqah & 35.1163 & 36.0883 & 79 & Bloudan & 33.7321 & 36.1251 \\
\hline 38 & Al Hatryiah & 35.1136 & 36.2108 & 80 & Kharabow & 33.5055 & 36.4655 \\
\hline 39 & T'aneita & 35.1070 & 36.0515 & 81 & Sayyidah Zaynab & 33.4465 & 36.3488 \\
\hline 40 & Al Kadmous & 35.0991 & 36.1642 & 82 & Ein Al Sha'ara & 33.3741 & 35.9355 \\
\hline 41 & Al Qadhboun & 35.0979 & 36.2420 & 83 & Heineh & 33.3487 & 35.9465 \\
\hline 42 & Karm Al Teen & 35.0975 & 36.1135 & & & & \\
\hline
\end{tabular}

Tartus area. The arid regions around Homs extending to the south near Damascus are void of natural forests. Populations of the Persian squirrel start to appear west of Damascus, where the natural oak forests in Zabadani and Bludan close to the border between Syria and Lebanon 
are abundant. Small populations were reported east of Damascus in the Ghota area, and from Mount Hermon, mainly in an agricultural area with fruit and walnut trees.

\section{$\mathrm{Ha}$ a it a t}

The Persian squirrel is associated with oak (Quercus coccifera and Quercus calliprinos), pine (Pinus brutia and Pinus halepensis), hawthorn (Crataegus sp.), bay tree (Laurus nobilis), and cedar (Cedrus libani) forests. Most of the natural forests in Syria are located along the coastal mountains with an estimated area of $2,576 \mathrm{~km}^{2}$, mostly dominated by Quercus calliprinos and Quercus infectoria, and associated with Crataegus azarolus, Laurus nobilis, Prunus ursine, and Pyrus syriaca. Pine forests of Pinus brutia are found around the Lattakia area. Cedar forests are located at higher altitudes ranging between $900-1560 \mathrm{~m}$ a. s. 1., associated with the Cilician fir (Abies cilicica).

The natural forests in Syria are mainly concentrated around the coastal areas of Lattakia and Tartus, and in the inland near Hama, rural areas of Damascus and Idleb, accounting for about $81 \%$ of the total forest area (MoHAmED et al. 2020).

Sciurus anomalus takes refuge in dense forests, especially oak, and frequent farms to feed on walnut trees and others (Figs. 2, 3). They are usually observed either on the ground searching for food or feeding on grasses, or in trees, hiding or feeding on fresh green pine cones growing

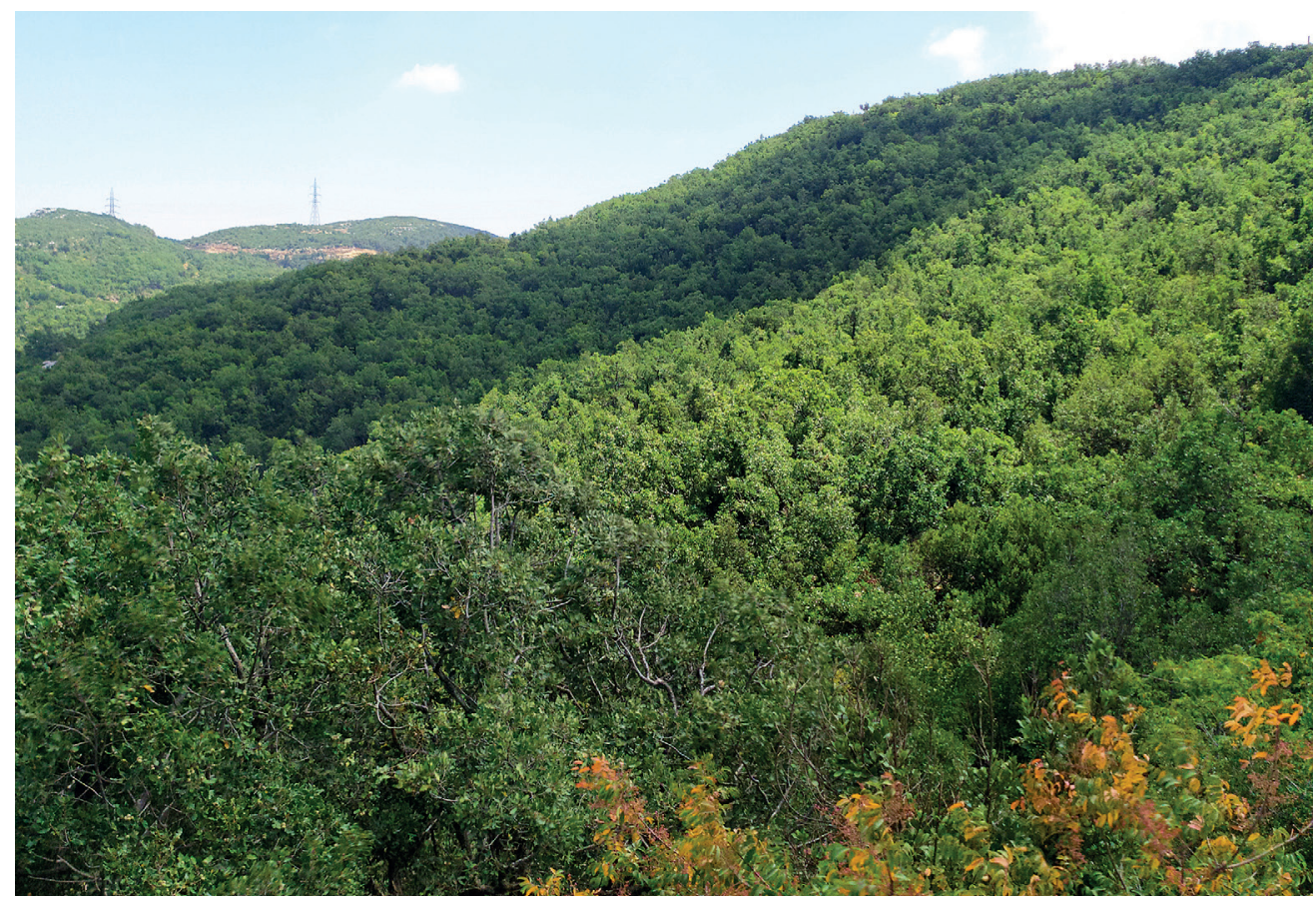

Fig. 2. A forest near Al Qadhboun in northern Syria with oak trees. 

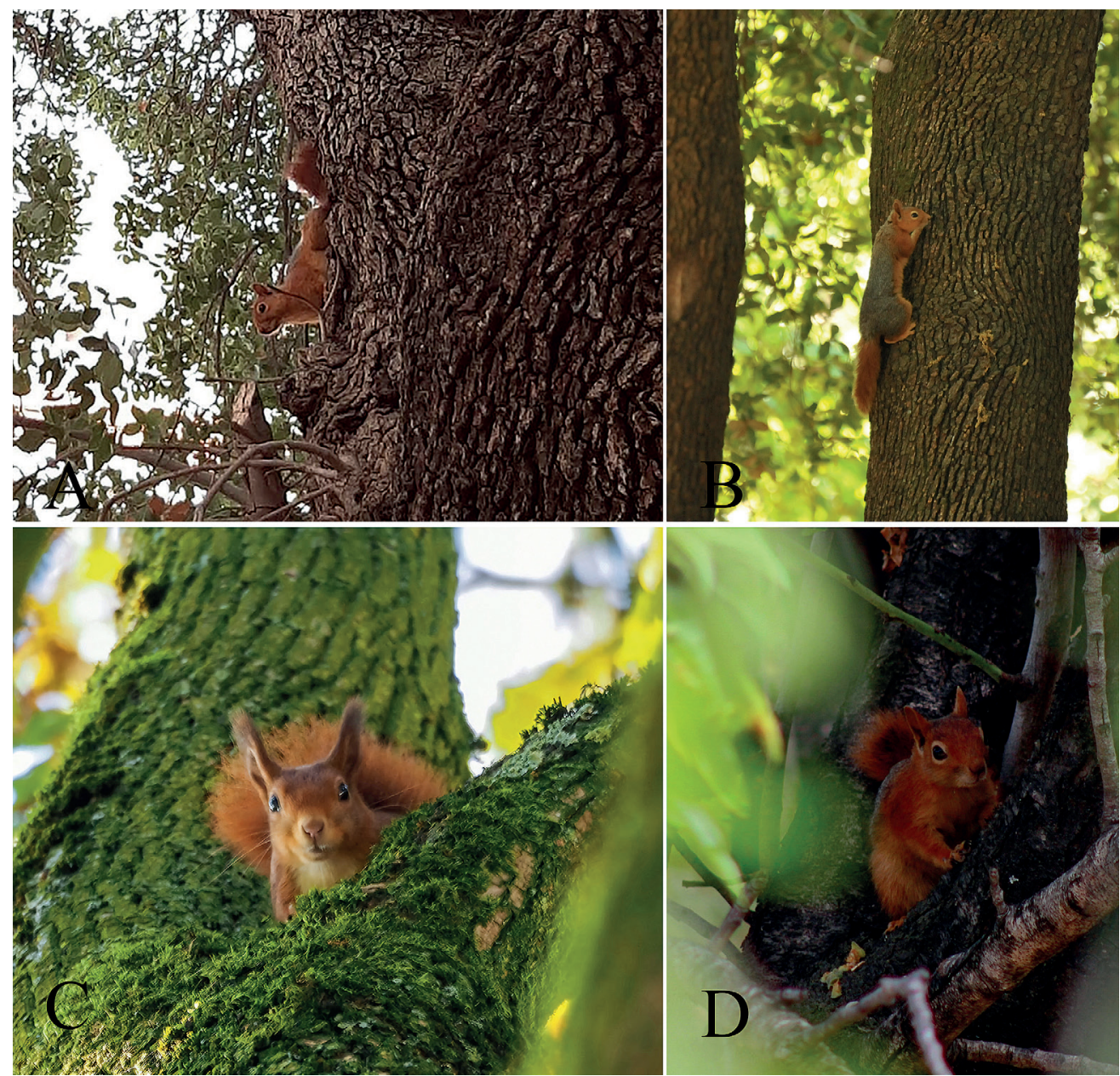

Fig. 3. Persian squirrels observed in Syria. A - Beshraghi (photo by I. SALEH). B - Jaiboul (photo by H. Al Khatib). C - Slenfeh (photo by T. Ismaiel). D - Al Qteilbiyah (photo by H. Al Hakeem).

on the tree tops. Nests are usually located in holes of oak trees with one opening several metres above ground (Fig. 4).

The Persian squirrel feeds on oak acorns as well as pine cones. Remains of the eaten fresh pine cones are found scattered on the forest floor, while oak acorns are usually found in tree holes used as a nest. Only individual squirrels were observed in most cases, however, one of us (AA) came across ten and twenty individuals either individually or in pairs near Abu Qubays and in a small forest near Mashqita in 2008, respectively, both with dense oak and pine forests. In some cases, squirrels were sighted near houses with cultivated trees. 

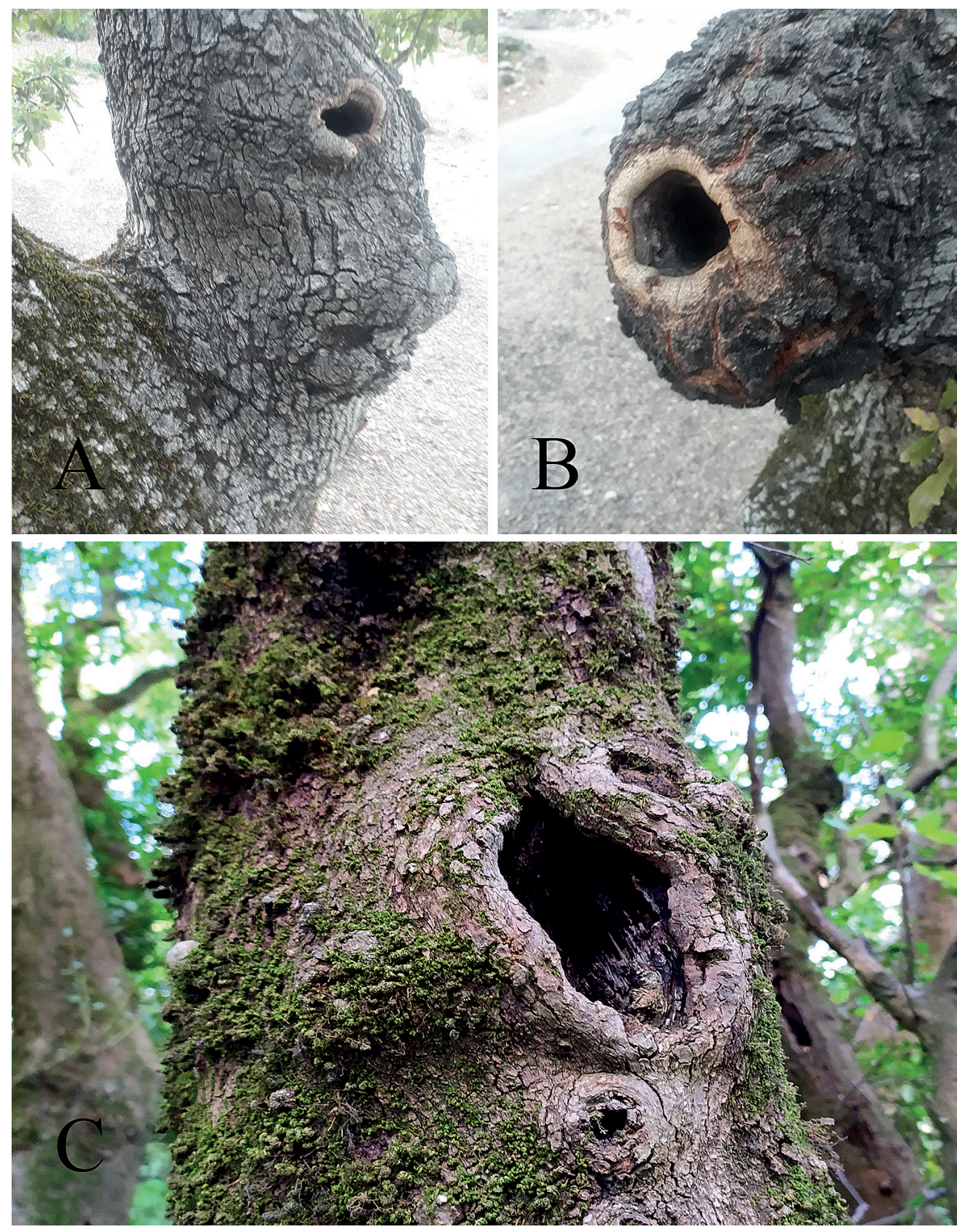

Fig. 4. Persian squirrel's nests in tree holes of oak forests in Al Kadmous (photo by A. HaEdAR \& M. AL-ALI). 


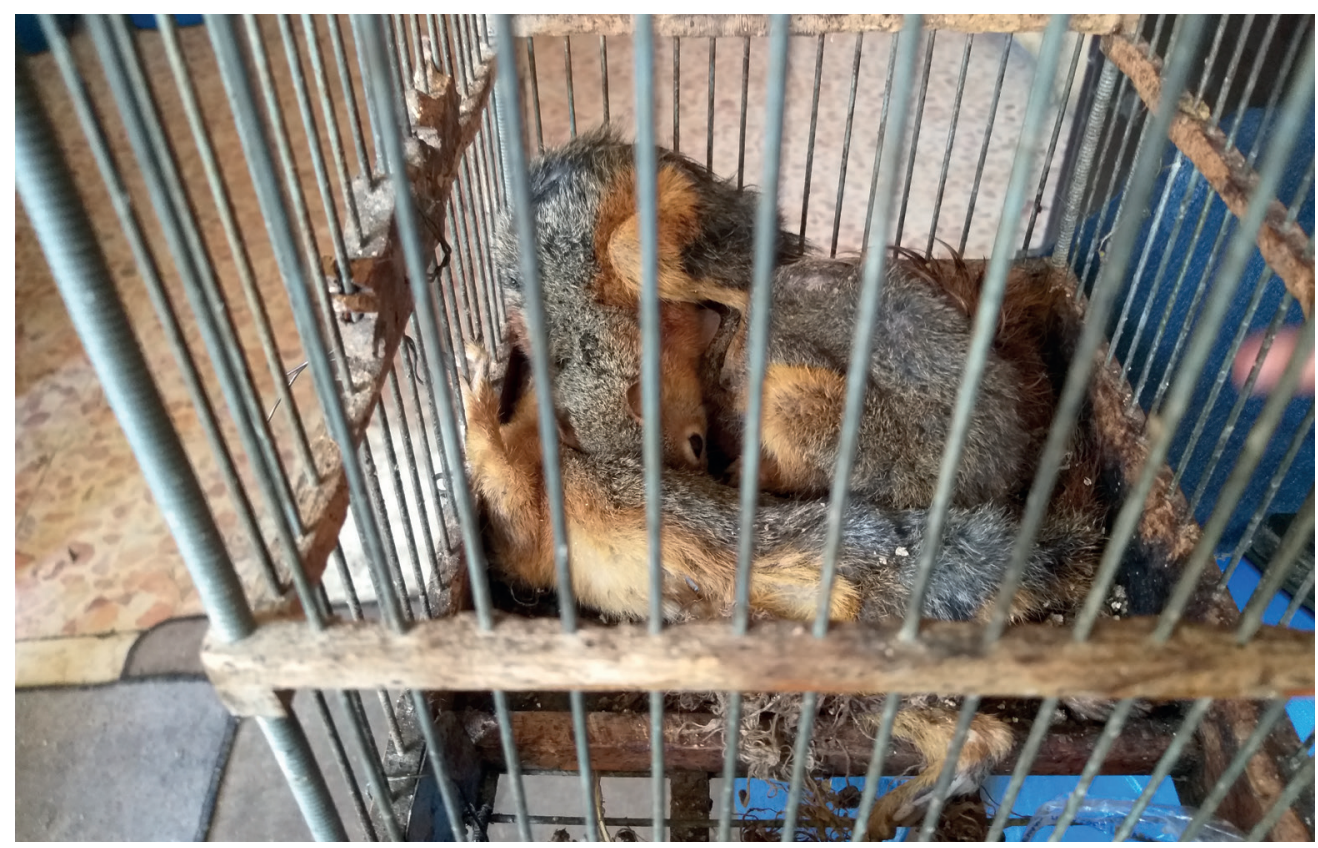

Fig. 5. Caged Persian squirrel offered for sale in a local market.

\section{Reproduction}

There are two seasons for the birth of squirrels in Syria. The main season is in the spring and lasts from late March until early May, and the other season is in the autumn and extends from the end of October until early November. Nesting generally occurs in hollows of oak trees, sometimes the parents build a high nest on pine trees, and when there is no suitable place for nesting, squirrels nest in rocky cliffs. In Greece, breeding occurs from April to May and August to September (Hecht-MARKou 1994), while in Transcaucasia, the breeding season lasts from early February to April, and then during mid-July to late August (OGNEv 1966, Hecht-Markou 1994).

\section{Threats and human interaction}

There is a conflict with the local people in the majority of areas where the Persian squirrel was observed. Squirrels feed on walnut and almond plantations. In addition, they consume pomegranates, figs, and other crops. These crops are considered very valuable for farmers with a high market price. Squirrels are thus regarded as agricultural pests, and as a result, they are killed in several ways (i.e. shooting, trapping, and poisoning) to avoid economic loss. Sometimes the squirrels are killed indirectly by traps that are placed for other animals, and they are also attached to traps that contain adhesive materials used for bird hunting, in addition to nets that are set for bird hunting. 
On the other hand, wildlife trade is currently flourishing in Syria as a result of poor enforcement of wildlife laws for the protection of wildlife and their trade enacted in 1970. Young squirrels are caught and offered for sale in cages at markets in Damascus, Lattakia, and Tartus. Squirrel hunters dig into the tree just below the squirrel's nest hole, making a new hole, shortly after the birth of the young, they uncover the thin crust between the nest hole and the new hole they made, then capturing the young individuals. The animals are kept in cramped cages and under poor sanitary conditions (Fig. 5). They are sold for about $\$ 20$ each. Also, in some instances, squirrels are smuggled to Lebanon and Jordan for sale.

On the other hand, squirrels are killed by hunters without any justification, since hunting in Syria has turned from a hobby to extermination of wildlife. Squirrels are not consumed by the locals or prescribed for folk medicine. Captured animals are kept in cages as pets, however they do not survive and die soon after. Some others are sold as mummified animals.

The stone marten, Martes foina (Erxleben, 1777), is one of the natural enemies preying on young squirrels. The stone marten was observed on several occasions to attack squirrel nests and devour the young.

Deforestation has increased over the years through acquisition of land for agriculture, logging to produce fuelwood and charcoal, and urbanization especially in the mountains. Forest fires are not a direct result of war, but rather caused by natural or intentional causes. Sometimes the fire spreads in forests during charcoal making or when farmers burn their crop residues.

\section{Conclusions}

This preliminary study sheds light on the urgent need to investigate the ecology and biology of the Persian squirrel in Syria, and to identify further threats affecting its current population. Other avenues include molecular identification of the current populations in Jordan, Lebanon, and Syria.

\section{Acknow ledgements}

Our thanks are extended to Laya MAJED, Geographic Information System Officer (Royal Society for the Conservation of Nature, Jordan) for the map preparation. We wish to thank Arfan HAEDER, Yaman OMRAN, and Mahmoud AL-ALI for their help in data gathering, providing photos and fieldwork, and Ibrahim SALEH, Haitham Al KhatiB, Taher Ismaiel, and Hussien Al HaKeEm for providing photographs.

\section{REFERENCES}

Abi-Said M. R., El Khoury J., Makhlouf H. \& Amr Z. S., 2014: Ecology of the Persian squirrel, Sciurus anomalus, in Horsh Ehden Nature Reserve, Lebanon. Vertebrate Zoology, 64: 127-135.

Amr Z., Eid E., QARQAZ M. A. \& Abu BAKER M., 2006: The status and distribution of the Persian squirrel, Sciurus anomalus (Mammalia: Rodentia: Sciuridae), in Dibbeen Nature Reserve. Zoologische Abhandlungen - Staatliches Museum für Tierkunde Dresden, 55: 199-207.

GAvish L., 1993: Preliminary observations on the behavior and ecology of free-living populations of the subspecies Sciurus anomalus syriacus (golden squirrel) on Mount Hermon, Israel. Israel Journal of Zoology, 39: 275-280.

Grimmberger E. \& Rudloff K., 2009: Atlas der Säugetiere Europas, Nordafrikas und Vorderasiens. Natur und Tier Verlag GmbH, Münster, 466 pp.

Harrison D. L. \& Bates P. J., 1991: The Mammals of Arabia. Harrison Zoological Museum, Kent, $354 \mathrm{pp}$. 
Неснт-Marкou P., 1994: Beschreibung, geographische Verbreitung, Biotope und Ortswechsel des Sciurus anomalus Gueldenstadt, 1785 auf der Insel Lesbos (Griechentand). Annales Musei Goulandris, 9: 429-443.

Koprowski J. L., Gavish L. \& Doumas S. L., 2016: Sciurus anomalus (Rodentia: Sciuridae). Mammalian Species, 48(934): 48-58.

KrYšTuFeK B. \& Vohralík V., 2005: Mammals of Turkey and Cyprus. Rodentia I: Sciuridae, Dipodidae, Gliridae, Arvicolinae. Annales Majora, Koper, 292 pp.

von Lehmann E., 1965: Über die Säugetiere im Waldgebiet N.W. Syriens. Sitzungsberichte der Gesellschaft Naturforschender Freunde zu Berlin (N. F.), 5: 22-38.

Mendelssohn H. \& Yom-Tov Y., 1999: Mammalia of Israel. Israel Academy of Sciences and Humanities, Jerusalem, $439 \mathrm{pp}$.

Mohamed M. A., Anders J. \& Schneider C., 2020: Monitoring of changes in land use/land cover in Syria from 2010 to 2018 using multitemporal landsat imagery and GIS. Land, 9: 226.

OGNEv S. I., 1966: Mammals of the USSR and Adjacent Countries. Rodents. Volume 4. Israel Program for Scientific Translations, Jerusalem, $626 \mathrm{pp}$.

Shehab A. H., Amr Z. S \& Abu BaKer M. A., 2018: Rodents of southwestern Syria. Acta Societatis Zoologicae Bohemicae, 82: 177-194.

Tristram H. B., 1866: Report on the mammals of Palestine. Proceedings of the Zoological Society of London, 1866: 84-93. 